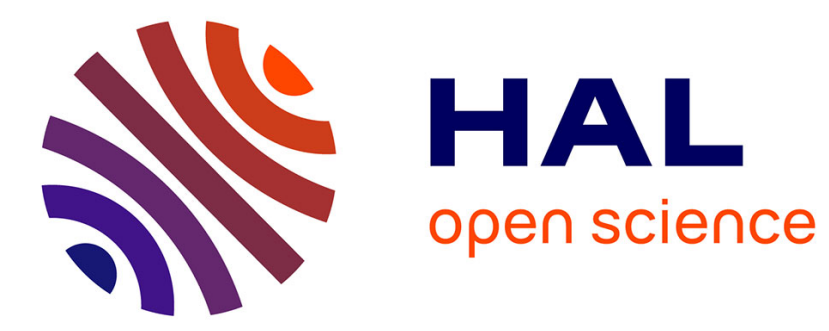

\title{
A Novel Multi-Criteria Risk Matrix to Assist in the Strategy Formulation Process: The Case of SMEs
} Jean-Marc Vasnier, Mourad Messaadia, Nicolas Maranzana, Ameziane

Aoussat

\section{- To cite this version:}

Jean-Marc Vasnier, Mourad Messaadia, Nicolas Maranzana, Ameziane Aoussat. A Novel MultiCriteria Risk Matrix to Assist in the Strategy Formulation Process: The Case of SMEs. International Journal of Information Technology and Decision Making, 2021, 20 (03), pp.987-1009. $10.1142 / \mathrm{s} 0219622021500255$. hal-03295416

\section{HAL Id: hal-03295416 \\ https://hal.science/hal-03295416}

Submitted on 22 Jul 2021

HAL is a multi-disciplinary open access archive for the deposit and dissemination of scientific research documents, whether they are published or not. The documents may come from teaching and research institutions in France or abroad, or from public or private research centers.
L'archive ouverte pluridisciplinaire HAL, est destinée au dépôt et à la diffusion de documents scientifiques de niveau recherche, publiés ou non, émanant des établissements d'enseignement et de recherche français ou étrangers, des laboratoires publics ou privés. 


\title{
A Novel Multi-Criteria Risk Matrix to Assist in the Strategy Formulation Process: The Case of SMEs
}

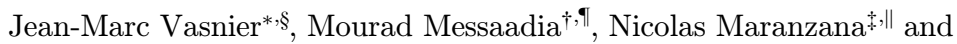 \\ Ameziane Aoussat,*** \\ ${ }^{*}$ Cesi Campus Saint-Nazaire, 1 Bd de l'Université, CS 70152 \\ F-40603 Saint-Nazaire, France \\ ${ }^{\dagger}$ Lineact Cesi Campus Rouen \\ F-76808 Saint Etienne de Rouvray, France \\ ${ }^{\star}$ Arts et Metiers Institute of Technology \\ LCPI, HESAM Université \\ F-75013 Paris, France \\ \$jmvasnier@cesi.fr \\ Tmmessaadia@cesi.fr \\ "nicolas.maranzana@ensam.eu \\ **ameziane.aoussat@ensam.eu
}

\begin{abstract}
Small and medium-sized enterprises (SMEs) are the spine of the European economy and play a key role in adding value in all sectors of the economy. However, due to a lack of methodology and time, SME entrepreneurs struggle to formalize their strategies and too often remain illprepared to face today's potential crises. This paper aims to propose a Risk Management (RM) tool to identify and assess the impact of risks on specific business strategic dimensions. The hypotheses and robustness of the model are tested using Monte Carlo simulation. The analysis shows that a reduced strategic risk matrix (size $4 \times 4$ ) could provide the same quality of information as a full strategic risk matrix (size $20 \times 10$ ) in about $80 \%$ of the cases, regardless of the weight of each criterion and the values of each risk factor. The results extend the limited use of RM tool in the field of SME Risk Management.
\end{abstract}

Keywords: Decision analysis; strategic risk management; Monte Carlo simulation; risk matrix; SMEs.

\section{Introduction}

In the era of the fourth industrial revolution, Small and Medium-sized Enterprises (SMEs) are competing to improve their efficiency while retaining the interests of their customers. Compared to large companies, SMEs are usually seen as having simpler internal organization and are therefore more flexible and quicker to react and adapt to change. Unfortunately, many SME leaders have some difficulties in establishing a coherent and optimized strategy due to lack of time, methodology,

$\S$ Corresponding author. 
resources and/or know-how ${ }^{1}$ Too often, they remain unprepared to deal with today's potential crises: strikes, insufficient cash reserves, earthquakes, pandemic, etc. and prefer to react to change by taking short-term measures. ${ }^{2}$ Previous studies have shown that due to their financial constraints, SMEs focus on less risky rather than on growth-orientated strategies. ${ }^{3}$

Risk Management (RM) can help SME leaders identify significant risks that could jeopardize the success or existence of their business in time to deal with them effectively. ${ }^{3}$ Unfortunately, RM tools used by large companies are generally not suitable for SMEs because they are either too expensive or too complex. ${ }^{4}$ Adopting RM tools using the same guidelines as those defined for large firms would require considerable time and effort from SMEs. Also, they are rarely used in a SME context, although there is evidence that businesses that adopt RM strategies are more likely to survive and grow. ${ }^{5}$ The concepts of risk and strategy in large firms are widely discussed in the literature, but only a few academic studies have addressed the topic of RM in SMEs. ${ }^{6-10}$ Even if Kraja and Osmani ${ }^{7}$ identify that to foster a profitable business and a sustainable competitive advantage, SME leaders need to understand their internal and external environments. The survival of small businesses depends on their ability to develop flexible and effective responses to the challenges of the competitive environment. ${ }^{11}$

$\mathrm{RM}$ is a global process that fosters innovation in business processes. To use it effectively, it must be supported by a knowledge base and a decision support system. ${ }^{8}$ Through a business strategy based on a risk management process, SMEs improve their resilience and reduce their instinctive approach to business management. Human resources become more knowledgeable on risk mitigation techniques, being able to better control the business when confronted to adverse risks. ${ }^{11}$

A gap was identified in the design of an RM tool, which could help SMEs leaders identify their strategic risks and assess their impacts on the key business strategic dimensions. Therefore, the objectives of this study are (i) to identify the key components of a strategic risk matrix; (ii) to propose a strategic risk matrix adapted to SMEs and (iii) to validate the hypotheses and robustness of the proposed matrix by using Monte Carlo simulation. The research paper is structured as follows: the first section provides an overview of the existing literature on the subject, and then the research model is introduced with its relevance for the design of a strategic risk matrix. The third section presents the methodology, hypotheses, data analysis and results. Finally, the paper concludes with a discussion around the findings and the future directions of the research.

\section{Risk Management Process}

None of the available international standards (ISO 31000 and COSO Report) explain how to apply RM to specific situations faced by SMEs. ${ }^{8}$ As a result, the overall approach to risk is almost entirely influenced by the knowledge level of the SME leader, which has a critical impact on the business strategy and its implementation. ${ }^{3}$ 
Unfortunately, not many leaders are well prepared for risk management and, in general, they "learn by doing". As human resources for "risk" related tasks are very limited in SMEs, risks are not accurately identified, and the risk assessment is only occasionally and subjectively carried out by the leader or the board of directors. ${ }^{12} \mathrm{As}$ defined by Chatterjee et al., ${ }^{13}$ Strategic Risk Management (SRM) is a continuous process of identifying and assessing strategic risks (i.e., human, technological, brand, competition and project risks), which are considered obstacles to achieving an organization's financial and operational objectives. The risk management process consists of three steps: (i) risk identification, (ii) risk assessment, (iii) risk management.

\subsection{Risks identification}

In the SRM field, the identification of strategic risks is an extremely important topic as they directly affect the company's objectives. ${ }^{4}$ First of all, the risk assessment must go through a rigorous process of identifying its internal and external risks. ${ }^{14}$ Often, the company cannot control the occurrence of these risks, but an appropriate risk management process can mitigate their effects. External risks are related to the macro-environment and competitive environment in which the SME operates and are best identified through brainstorming, interviews, risk surveys, PESTEL or Fiveforces analysis. ${ }^{15}$ The competitive environment is defined as the ecosystem in which the SME buys, sells goods or services that it produces, and competes with its challengers; and the macro-environment as the set of political, economic, social, technological, legal and environmental factors that affect the company's activities. Internal risks are related to the company's processes and resources and should be assessed through Four-corner's or value chain analysis. The list of the most recurring risks identified in the literature is presented in Table 1.

People are central to the success of SMEs. ${ }^{14}$ Therefore, in order for the risk identification to be relevant and to guard against risk perception bias, the analysis must follow a well-structured process and be carried out by a team. ${ }^{22}$

\subsection{Risk assessment}

The literature review revealed that SMEs often struggle to manage their risks due to a lack of human and financial resources. ${ }^{23}$ Lack of adequate risk management is one of the main reasons of SMEs failure; also a risk identification process should be deployed in every SMEs to detect any threats early enough to address them. Strategic risk assessment is often performed through a Strength-Weakness-OpportunityThreat (SWOT) analysis. According to the four axes, the organization evaluates itself in relation to the competition and the environment. The SWOT analysis, if correctly applied, will often yield targeted and constructive results at the corporate or departmental level. ${ }^{24}$ The main shortcoming of SWOT is that it provides only qualitative assessments of the factors identified and is only a basic reference point for formulating a valid strategy. ${ }^{25}$ In order to overcome these gaps, the main internal 
Table 1. Risk families and factors.

\begin{tabular}{|c|c|c|c|c|c|c|c|c|}
\hline Risk families & Risk factors & $(16)$ & $(7)$ & $(17)$ & (18) & $(19)$ & $(20)$ & $(21)$ \\
\hline Macro environment & $\begin{array}{c}\text { Legal } \\
\text { Environmental } \\
\text { Social } \\
\text { Economic } \\
\text { Technological } \\
\text { Political }\end{array}$ & $\checkmark$ & & $\begin{array}{l}\checkmark \\
\checkmark \\
\checkmark \\
\checkmark\end{array}$ & $\checkmark$ & $\begin{array}{l}\checkmark \\
\checkmark\end{array}$ & $\begin{array}{l}\checkmark \\
\checkmark\end{array}$ & $\begin{array}{l}\checkmark \\
\checkmark \\
\checkmark \\
\checkmark \\
\checkmark\end{array}$ \\
\hline Competitive environment & $\begin{array}{c}\text { Buyer Power } \\
\text { Competitors Rivalry } \\
\text { Substitutes } \\
\text { New Entrants } \\
\text { Supplier Power }\end{array}$ & $\begin{array}{l}\checkmark \\
\checkmark \\
\checkmark \\
\checkmark \\
\checkmark\end{array}$ & $\begin{array}{l}\checkmark \\
\checkmark \\
\checkmark \\
\checkmark \\
\checkmark\end{array}$ & $\begin{array}{l}\checkmark \\
\checkmark\end{array}$ & $\begin{array}{l}\checkmark \\
\checkmark\end{array}$ & $\begin{array}{l}\checkmark \\
\checkmark\end{array}$ & $\begin{array}{l}\checkmark \\
\checkmark\end{array}$ & $\begin{array}{l}\checkmark \\
\checkmark \\
\checkmark \\
\checkmark \\
\checkmark\end{array}$ \\
\hline Primary activities & $\begin{array}{l}\text { Inbound Logistics } \\
\text { Operations } \\
\text { Outbound Logistics } \\
\text { Marketing \& Sales } \\
\text { Services }\end{array}$ & & $\begin{array}{l}\checkmark \\
\checkmark\end{array}$ & $\begin{array}{l}\checkmark \\
\checkmark \\
\checkmark\end{array}$ & $\begin{array}{l}\checkmark \\
\checkmark \\
\checkmark \\
\checkmark\end{array}$ & $\begin{array}{l}\checkmark \\
\checkmark \\
\checkmark\end{array}$ & $\begin{array}{l}\checkmark \\
\checkmark \\
\checkmark\end{array}$ & $\begin{array}{l}\checkmark \\
\checkmark\end{array}$ \\
\hline Support activities & $\begin{array}{c}\text { Firm Infrastructure } \\
\text { HR Management } \\
\text { Technology } \\
\text { Procurement }\end{array}$ & & $\begin{array}{l}\checkmark \\
\checkmark\end{array}$ & $\begin{array}{l}\checkmark \\
\checkmark \\
\checkmark \\
\checkmark\end{array}$ & $\begin{array}{l}\checkmark \\
\checkmark \\
\checkmark\end{array}$ & $\begin{array}{l}\checkmark \\
\checkmark\end{array}$ & $\begin{array}{l}\checkmark \\
\checkmark\end{array}$ & $\begin{array}{l}\checkmark \\
\checkmark\end{array}$ \\
\hline
\end{tabular}

and external risks are identified, and the risk assessment will reveal their impacts (as opportunities or threats) on the main strategic dimensions. The risk assessment consists of three steps: (i) identify the SME strategic dimensions, (ii) analyze each risk and finally (iii) quantify and rank the impact of risk factors on the strategic dimensions.

\subsubsection{Strategic dimensions}

Due to the volatile nature of today's global marketplace, it is essential for SMEs to monitor the performance of their processes and align them with the enterprise's strategic objectives. To do so, most companies use Performance Measurement System (PMS) ${ }^{26}$ However, data suggest that only $14 \%$ of employees understand their company's strategy and $85 \%$ of management teams spend less than one hour per month discussing strategy. ${ }^{27}$ Therefore, the use of Performance Measurement Systems (PMS) is essential for SMEs not only to communicate the company's strategy, facilitate its execution and monitor its implementation but also to formalize it. ${ }^{26}$ The most widely used PMS method in all industries by small and large organizations in North America is the Balanced Scorecard (BSC). ${ }^{28}$

A critical step in the deployment of BSC in SMEs is the identification and prioritization of the strategic vision. ${ }^{29}$ SMEs focus mainly on the operational and financial performance of their structure, while innovation, human resources, work climate, supplier relations and training are rarely measured. ${ }^{30}$ To facilitate the analysis, the most recurrent strategic dimensions (Table 2) identified in the literature 
Table 2. Strategic perspectives and dimensions.

\begin{tabular}{|c|c|c|c|c|c|c|c|c|c|c|c|}
\hline Strategic perspectives & Strategic dimensions & $(31)$ & $(32)$ & $(33)$ & $(34)$ & $(35)$ & $(36)$ & $(37)$ & $(38)$ & $(39)$ & $(40)$ \\
\hline Finance & Finance & $\checkmark$ & $\checkmark$ & $\checkmark$ & $\checkmark$ & & & $\checkmark$ & $\checkmark$ & & $\checkmark$ \\
\hline \multirow[t]{2}{*}{ Customer } & $\begin{array}{l}\text { Product and Service } \\
\text { Quality }\end{array}$ & & $\checkmark$ & $\checkmark$ & $\checkmark$ & $\checkmark$ & $\checkmark$ & $\checkmark$ & $\checkmark$ & $\checkmark$ & $\checkmark$ \\
\hline & $\begin{array}{l}\text { Customer Relations } \\
\text { Alliances (customers or } \\
\text { academic partners) }\end{array}$ & $\checkmark$ & $\checkmark$ & $\begin{array}{l}\checkmark \\
\checkmark\end{array}$ & $\checkmark$ & $\checkmark$ & & $\begin{array}{l}\checkmark \\
\checkmark\end{array}$ & $\checkmark$ & $\checkmark$ & $\checkmark$ \\
\hline Internal & $\begin{array}{l}\text { Operational Performance } \\
\text { QHSE Performance } \\
\text { Supplier Relations }\end{array}$ & $\begin{array}{l}\checkmark \\
\checkmark \\
\checkmark\end{array}$ & $\checkmark$ & $\begin{array}{l}\checkmark \\
\checkmark \\
\checkmark\end{array}$ & $\checkmark$ & $\checkmark$ & $\checkmark$ & $\begin{array}{l}\checkmark \\
\checkmark\end{array}$ & $\checkmark$ & $\begin{array}{l}\checkmark \\
\checkmark\end{array}$ & $\begin{array}{l}\checkmark \\
\checkmark \\
\checkmark\end{array}$ \\
\hline \multirow[t]{3}{*}{$\begin{array}{l}\text { Learning \& } \\
\text { Innovation }\end{array}$} & $\begin{array}{l}\text { Human resources/ } \\
\text { Employee } \\
\text { relations }\end{array}$ & $\checkmark$ & $\checkmark$ & $\checkmark$ & & & $\checkmark$ & $\checkmark$ & $\checkmark$ & & $\checkmark$ \\
\hline & $\begin{array}{l}\text { Product and Services } \\
\text { Innovation }\end{array}$ & $\checkmark$ & & $\checkmark$ & & $\checkmark$ & & $\checkmark$ & $\checkmark$ & $\checkmark$ & \\
\hline & Community & & & $\checkmark$ & & & & & & & $\checkmark$ \\
\hline
\end{tabular}

were associated with a business's four main activities (i.e., finance, customer, internal, learning and innovation). These are called Strategic Perspectives in a traditional Balanced Scorecard.

\subsubsection{Risks analysis}

Modern risk analysis has its roots in the fields of probability theory and disease treatment, so that specialists can identify the causal relationship between hazardous activities and negative health effects. A more recent definition of a risk analysis is "the process of assessing the likelihood of an adverse event". Assessing the level of risk is a complex subject because the quantification of probability and impact can be subjective and imprecise. ${ }^{41}$ In addition, the level of qualification of the individuals conducting the risk analysis may have an impact on the relevance of the exercise. ${ }^{42}$ In order to address these limitations, Marcelino-Sádaba et al. ${ }^{6}$ proposed a simplified process requiring the appraisal of the likelihood and severity of the risk on the basis of a six-level scale, as shown in Table 3. The risk factor is defined as

$$
R=P \times I,
$$

where $R$ is the risk level, $P$ is the probability (likelihood) and $I$ is the impact (severity).

\subsubsection{Strategic dimension's priority score}

In a strategic risk analysis, all factors are often considered to be equally important, but it must be taken into account that most factors do not have the same weight. ${ }^{43}$ For this reason, we will use the Analytical Hierarchy Process (AHP), which is a multi-criteria and weighted decision-making method proposed by Saaty. ${ }^{44} \mathrm{AHP}$ is based on the subdivision of the problem into a hierarchical form. AHP helps analysts 
Table 3. A six-level scale (likelihood/impact).

\begin{tabular}{lcrcc}
\hline & Likelihood & \multicolumn{2}{c}{ Impact } \\
\cline { 1 - 2 } Score $(P)$ & Description & & Score $(I)$ & Description \\
\hline 9 & Expected to occur & & $+/-9$ & Very high impact \\
7 & Very likely to occur & & $+/-7$ & High impact \\
5 & Likely to occur & & $+/-5$ & Medium impact \\
3 & Unlikely to occur & & $+/-3$ & Low impact \\
1 & Very unlikely to occur & & $+/-1$ & Very low impact \\
0 & Never & & 0 & None \\
\hline
\end{tabular}

to organize the critical aspects of a problem into a hierarchical structure similar to a decision tree. It allows to highlight the relationships between strategic risk factors and strategic dimensions. The Monte Carlo AHP (MCAHP) was used in our simulation, as MCAHP has produced reliable results in the construction, supply chain and finance. ${ }^{45-48}$ First, it enables the uncertainty of expert assessment to be included in the decision-making process by defining the pairwise comparisons as probability distributions rather than fixed values. Second, it provides the confidence level of each decision alternative. ${ }^{46}$ Third, it validates the robustness of the model by testing how small perturbations on weights can affect the final decision. ${ }^{49} \mathrm{~A}$ high-level representation of the Strategic Risk Matrix is shown in Fig. 1. The values associated to

\begin{tabular}{|c|c|c|c|c|c|c|c|c|c|c|c|c|c|c|}
\hline & & & & & & & & & egic Di & nensions & & & & \\
\hline & & & & & $\begin{array}{l}\stackrel{\mathscr{J}}{\mathscr{I}} \\
\text { 臬 }\end{array}$ & 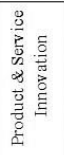 & 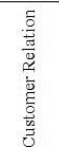 & 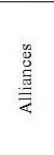 & 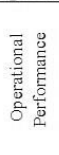 & 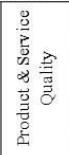 & 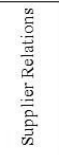 & 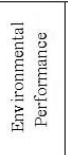 & 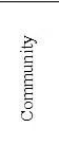 & 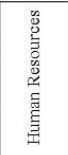 \\
\hline & & & & $1 \leq k \leq 10$ & Wds1 & Wds2 & Wds3 & Wds4 & Wds5 & Wds6 & Wds7 & Wds8 & Wds9 & Wds10 \\
\hline & & & & $1 \leq j \leq 4$ & Wb1 & & Wb2 & & & Wb3 & & & Wb4 & \\
\hline & & $1 \leq i \leq 20$ & $1 \leq p \leq 4$ & & Financial & & ustome & & & Internal & & Learn & ing \& $\mathrm{G}$ & rowth \\
\hline & Political & We1 & & & $\beta 1,1$ & $\beta 1,2$ & & & $\beta 1, \mathrm{k}$ & & & & & $\beta 1,10$ \\
\hline & Technological & We2 & & 离 & & & & & & & & & & \\
\hline & Environmental & We3 & W & ¿ & & & & & & & & & & \\
\hline & Economical & We4 & WaI & 吾 & & & & & & & & & & \\
\hline & Legal & We5 & & 音 & & & & & & & & & & \\
\hline$\cong$ & \begin{tabular}{|l|} 
Social \\
\end{tabular} & We6 & & & & & & & & & & & & \\
\hline 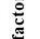 & Buyer & We7 & & & & & & & & & & & & \\
\hline$\frac{5}{y}$ & Supplier & We8 & & $\stackrel{\Xi}{\Xi}$ & & & & & & & & & & \\
\hline$E$ & New entrants & We9 & Wa2 & 产 & & & & & & & & & & \\
\hline 离 & \begin{tabular}{|l} 
Substitutes \\
\end{tabular} & We10 & & 莙 & $\beta \mathrm{i}, 1$ & $\beta \mathrm{i}, 2$ & & & $\beta \mathrm{i}, \mathrm{k}$ & & & & & $\beta \mathrm{i}, 10$ \\
\hline$\stackrel{\bar{g}}{g}$ & Rivalry & We11 & & & & & & & & & & & & \\
\hline 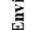 & \begin{tabular}{|l|} 
Inbound logistics \\
\end{tabular} & We12 & & & & & & & & & & & & \\
\hline 党 & Operations & We13 & & $\frac{1}{g}=$ & & & & & & & & & & \\
\hline क & \begin{tabular}{|l} 
Outbound logistics \\
\end{tabular} & We14 & Wa3 & 产 & & & & & & & & & & \\
\hline & Marketing & We15 & & $\bar{\Xi}=$ & & & & & & & & & & \\
\hline & Service & We16 & & & & & & & & & & & & \\
\hline & Infrastructure & We17 & & & & & & & & & & & & \\
\hline & Technology & We18 & Wh & $\overline{\mathrm{g}}$ & & & & & & & & & & \\
\hline & Procurement & We19 & Wat & 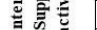 & & & & & & & & & & \\
\hline & HR & We20 & & & $\beta 20,1$ & $\beta 20,2$ & & & $\beta 20, \mathrm{k}$ & & & & & $\beta 20,10$ \\
\hline
\end{tabular}

Fig. 1. Full strategic risk matrix $($ size $20 \times 10)$. 
each risk factor are then inserted into the multiple linear regression model to calculate the priority score $(D S)$ of each strategic dimension.

The priority score $D S_{j, k}^{(20 \times 10)}$ is calculated using

$$
D S_{j, k}^{(20 \times 10)}=\frac{\begin{array}{c}
w_{a, 1} \times \sum_{i=1}^{6} w_{e, i} \times \beta_{i, k}+w_{a, 2} \times \sum_{i=7}^{11} w_{e, i} \times \beta_{i, k}+w_{a, 3} \\
\times \sum_{i=12}^{16} w_{e, i} \times \beta_{i, k}+w_{a, 4} \times \sum_{i=17}^{20} w_{e, i} \times \beta_{i, k}
\end{array}}{\left(1-w_{b, j} \times w_{d s, k}\right)},
$$

where $D S_{j, k}$ is the priority score of each strategic dimension $k, w_{e, i}$ is the weight of each risk factor, $w_{a, p}$ is the weight of each risk family, $w_{d s, k}$ is the weight of each strategic dimension, $w_{b, j}$ is the weight of each strategic perspective, with $j=1$ to 4 , $i=1$ to $20, p=1$ to $4, k=1$ to 10 .

\subsection{Risk management}

Risk management in broadest sense seeks to organize appropriate strategies to deal with the risks. Strategy is a word with many meanings, all of which are relevant and useful for those who are responsible for defining their organization's strategy. Historically, the term strategy derives from the Greek word strategos, which means "general", or as defined by BH Liddell Hart, "the art of distributing and applying military means to fulfill the ends of policy". Frédéric Le Roy defines it as the act of determining clear objectives, aligned with the understanding of the environment, then on the allocation of the available resources for a sustainable competitive advantage. ${ }^{50}$ According to Ref. 51, risk management has three potential outcomes: an intolerable situation, a tolerable situation, and an acceptable situation. In intolerable situations, the source of the risk (such as a technology) must be reduced and the exposure limited. In tolerable situations, risks have to be managed. In acceptable situations, risk reduction efforts are not necessary, but it must still be ensured that benefits are obtained.

Each risk (Table 1) is appraised to determine its probability and severity for each strategic dimension (Table 2). The value of the risk level is then assigned to a specific area $\mathrm{L}$ (low), M (medium) or $\mathrm{H}$ (high) according to its value, whether negative (threat) or positive (opportunity). The zones: $\mathrm{L}-, \mathrm{M}-$, or $\mathrm{H}-$ represent areas of low, medium, or high threat, and $\mathrm{L}+, \mathrm{M}+$, or $\mathrm{H}+$ identify areas of low, medium, and high opportunity. ${ }^{52}$ The bias due to the interpretation of a numerical value is limited by the identification of risk zones (Table 4) and by respecting the axioms of a welldesigned risk matrix's axioms. ${ }^{53}$ The use of performance markers $(+,-)$ has been identified as critical by Ref. 54, in this way the display of data in a BSC format increases the weight of non-financial strategic dimensions.

The following research question emerged from the Risk Management survey: Can we simplify the risk assessment phase so that SME leaders can take actions based on data instead of feelings? 
Table 4. Threat-opportunity risk zones.

\begin{tabular}{lcc}
\hline Risk level & Risk zone & Effect \\
\hline$>+45$ & $\mathrm{H}+$ & Opportunity \\
$>+9$ and $<=+45$ & $\mathrm{M}+$ & \\
$<=+9$ & $\mathrm{~L}+$ & \\
$>=-9$ & $\mathrm{~L}-$ & Threat \\
$<-9$ and $>=-45$ & $\mathrm{M}-$ & \\
$<-45$ & $\mathrm{H}-$ & \\
\hline
\end{tabular}

\section{Proposed Research Model}

Making strategically sound decisions under conditions of uncertainty involves identifying a range of potential outcomes or even a discrete set of scenarios. In our case, risks are classified according to their origins (i.e., internal or external), and their impacts on the main strategic dimensions. In practice, most risks evolve over time, and the strategic risk matrix should have two main characteristics: the ability to identify all risks relevant for an SME, and the capacity to assess these risks quickly and easily. In our scenario, 20 risk factors and their impact on 10 strategic dimensions need to be appraised (Fig. 1). This means that 200 cells must be evaluated in order to calculate the priority score (DS) on each strategic dimension. This is time consuming and requires a lot of energy from the SME's leader or board of directors. Figure 1 demonstrates that there was a case for reducing this matrix $20 \times 10$ by a

\begin{tabular}{|c|c|c|c|c|c|c|c|c|c|c|c|c|c|c|}
\hline & & & & & & & & & egic Di & nensions & & & & \\
\hline & & & & & 总 & 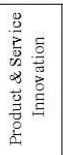 & 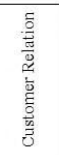 & 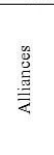 & 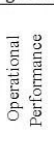 & 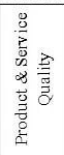 & 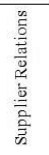 & 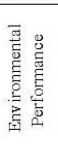 & 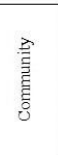 & 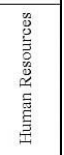 \\
\hline & & & & $1 \leq k \leq 10$ & Wds1 & Wds2 & Wds3 & Wds4 & Wds5 & Wds6 & Wds7 & Wds8 & Wds9 & Wds10 \\
\hline & & & & $1 \leq j \leq 4$ & Wb1 & & $\mathrm{Wb} 2$ & & & Wb3 & & & Wb4 4 & \\
\hline & & & $1 \leq p \leq$ & & Financial & & Custome & & & Internal & & Leart & $\operatorname{ng} \& \mathrm{G}$ & owth \\
\hline & & We1 & & & & & & & & & & & & \\
\hline & Political & We2 & & 总 & & & & & & & & & & \\
\hline & $\mid \begin{array}{l}\text { Technological } \\
\text { Environmentat }\end{array}$ & We3 & Wa1 & 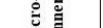 & 11 & & $a 12$ & & & 3 & & & 4 & \\
\hline & Economical Legal & We4 & & 五 & & & $0.1,2$ & & & $0.1,3$ & & & 01,4 & \\
\hline & Social Factors & We5 & & & & & & & & & & & & \\
\hline & & We6 & & & & & & & & & & & & \\
\hline 苟 & & We7 & & & & & & & & & & & & \\
\hline 孳 & Buver Supplier New & We8 & & 产 & & & & & & & & & & \\
\hline$E$ & entrants Substitutes & We9 & Wa2 & 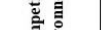 & $\alpha 2,1$ & & $\alpha 2,2$ & & & $\alpha 2,3$ & & & $\alpha 2,4$ & \\
\hline 岂 & Rivalry Factors & We10 & & $=$ & & & & & & & & & & \\
\hline 恶 & & We11 & & & & & & & & & & & & \\
\hline 息 & Inbound-Outbound & We12 & & & & & & & & & & & & \\
\hline 急 & logistics Operations & We13 & Wo3 3 & $\bar{\Xi} \cong$ & $x^{2} \geq 1$ & & ? & & & 32 & & & $x^{2}=$ & \\
\hline & Marketing Service & \begin{tabular}{|l|} 
We14 \\
We15
\end{tabular} & was & 可醇 & $0.0,1$ & & $0.5,2$ & & & $0.3,3$ & & & 0,4 & \\
\hline & & We16 & & & & & & & & & & & & \\
\hline & Infrastructure & We17 & & & & & & & & & & & & \\
\hline & Technology & We18 & Wa4 & 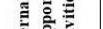 & $\alpha 4,1$ & & $\alpha 4,2$ & & & 04,3 & & & $a 4,4$ & \\
\hline & $\begin{array}{l}\begin{array}{l}\text { Procurement HR } \\
\text { Factors }\end{array} \\
\text { int }\end{array}$ & \begin{tabular}{|l} 
We19 \\
\end{tabular} & & & & & & & & & & & & \\
\hline & & We20 & & & & & & & & & & & & \\
\hline
\end{tabular}

Fig. 2. Reduced strategic risk matrix (size $4 \times 4)$. 


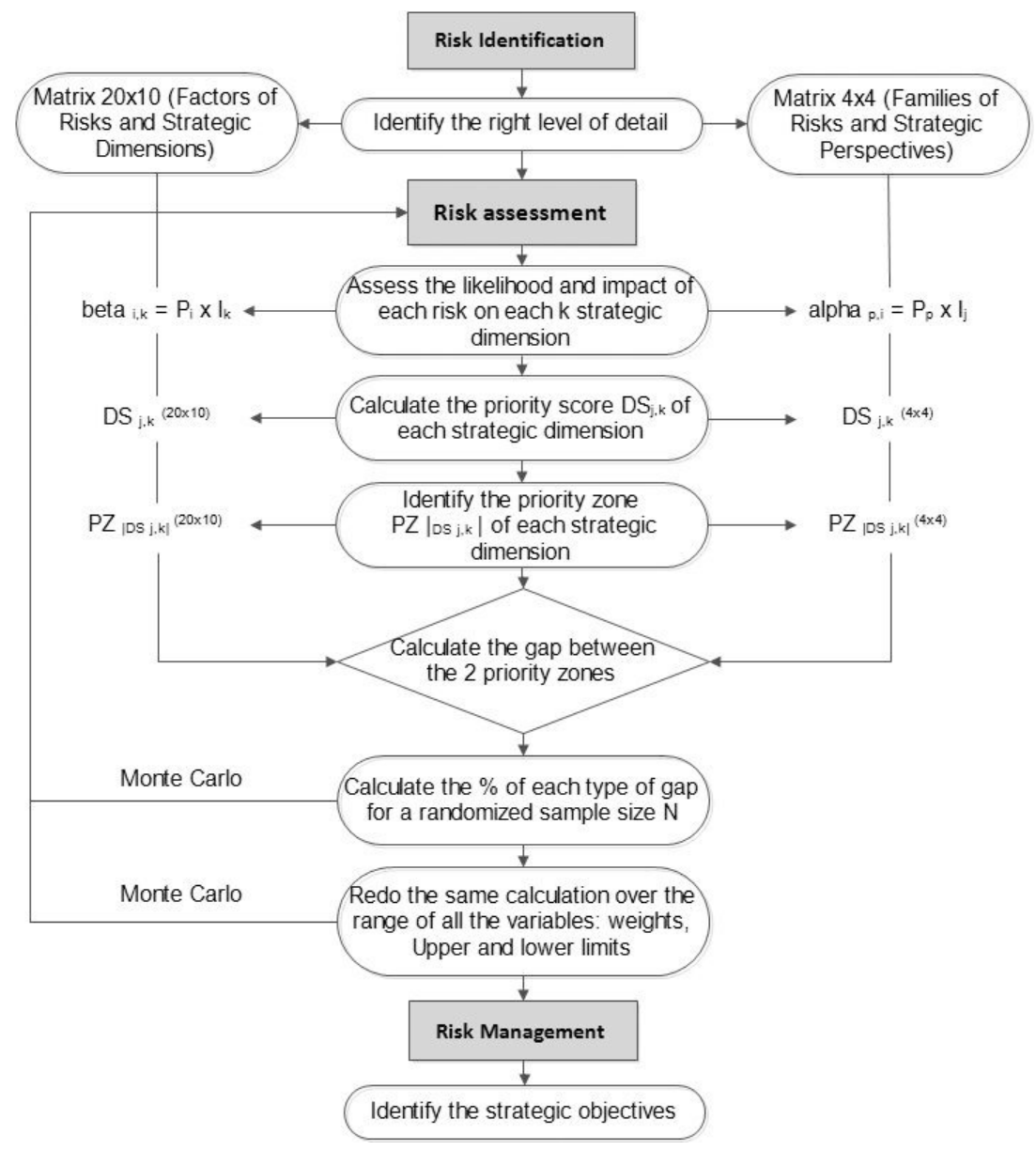

Fig. 3. Flowchart of the research process.

more manageable size matrix. In line with the research objectives, this paper examined whether a reduced strategic risk matrix (Fig. 2) can be used to simplify the risk assessment while retaining the same quality of results.

The simulation model can be represented as a seven-steps process organized in three sequential stages, namely risk identification, risk assessment and risk management (Fig. 3).

\section{Methodology and Hypotheses}

The means of comparing two risk matrixes in the literature are limited. The Monte Carlo simulation is used to assess all possible alternatives in relation to the weights of each criteria and risk factors. A computational algorithm that relies on repeated random sampling $(N=10,000$ to 100,000$)$ was developed in Excel and the data 
collected was analyzed with Minitab. Random numbers of $\alpha_{p, j}$ between $[-81,+81]$ were generated, each $\alpha_{p, j}$ were then used to generate a random cloud of values $\beta_{i, k}$ by using the inverse of the normal cumulative distribution for: a specified randomized probability $p_{\text {random }_{i, k}}$, a mean $\mu=\alpha_{p, j}$ and a standard deviation $\sigma_{t}$ as expressed in the following equation:

$$
\beta_{i, k}=\operatorname{norminv}\left(p_{\text {random }_{i, k}}, \alpha_{p, j}, \sigma_{t}\right),
$$

where $\alpha_{p, j}=P_{p} \times I_{j} . P_{p} \in[0,+9]$ and $I_{j} \in[-9,+9]$, each risk family $p$ is assessed to determine its likelihood and impact on each strategic perspective $j$.

The reduced priority scores $D S_{j, k}^{(4 x 4)}$ must satisfy in the following equation:

$$
D S_{j, k}^{(4 \times 4)}=\frac{w_{a, 1} \times \alpha_{1, j}+w_{a, 2} \times \alpha_{2, j}+w_{a, 3} \times \alpha_{3, j}+w_{a, 4} \times \alpha_{4, j}}{\left(1-w_{b, j} \times w_{d s, k}\right)} .
$$

The absolute value of $D S_{j, k}$ is then assigned to a specific priority zone (PZ) either: $\mathrm{L}$ (low), M (medium) or $\mathrm{H}$ (high) according to its value, either negative (threat) or positive (opportunity). An Upper Limit (UL) and a Lower Limit (LL) delimit each zone. The identification of a priority zone by using the guideline presented in Table 5 reduces the bias associated with the interpretation of a simple numerical value as identified in the SPACE model ${ }^{55}$ and meets the three axioms of a well-defined risk matrix. $^{56}$

Then, the gap between the two priority zones is calculated as follows:

$$
\operatorname{Gap}^{D S_{j, k}}=\left|P Z_{\left|D S_{j, k}^{(4 \times 4)}\right|}-P Z_{\left|D S_{j, k}^{(20 \times 10)}\right|}\right| \text { where } \operatorname{Gap}^{D S_{j, k}} \in[0,1,2,3] .
$$

The explanation of each Gap ${ }^{D S_{j, k}}$ is illustrated in Table 6.

The number of occurrences for each Gap is then divided by the sample size $N$ to give a ratio expressed as a percentage, which is named as $\% \operatorname{Gap}_{x} D S_{j, k}$,

Table 5. Priority zone identification.

\begin{tabular}{lccc}
\hline Conditional statement & Limits & Priority zone (PZ) & Strength \\
\hline If $\left|D S_{j, k}^{(4 \times 4)}\right|$ or $\left|D S_{j, k}^{(20 \times 10)}\right|$ is & $>$ Upper Limit (UL) then & 4 & High \\
& $>$ LL and <= UL & 2 & Medium \\
& $<=$ Lower Limit (LL) & 1 & Low \\
\hline
\end{tabular}

Table 6. Gap definition.

\begin{tabular}{lcl}
\hline Conditional statement & Result & Definition \\
\hline If Gap $\operatorname{GS}_{j, k}^{\text {DS equal to }}$ & 0 & The priority scores are assigned to the same zone. \\
& 1 & One priority score is assigned to zone 1 and the other to zone 2. \\
& 3 & One priority score is assigned to zone 2 and the other to zone 4. \\
& 3 & One priority score is assigned to zone 1 and the other to zone 4.
\end{tabular}




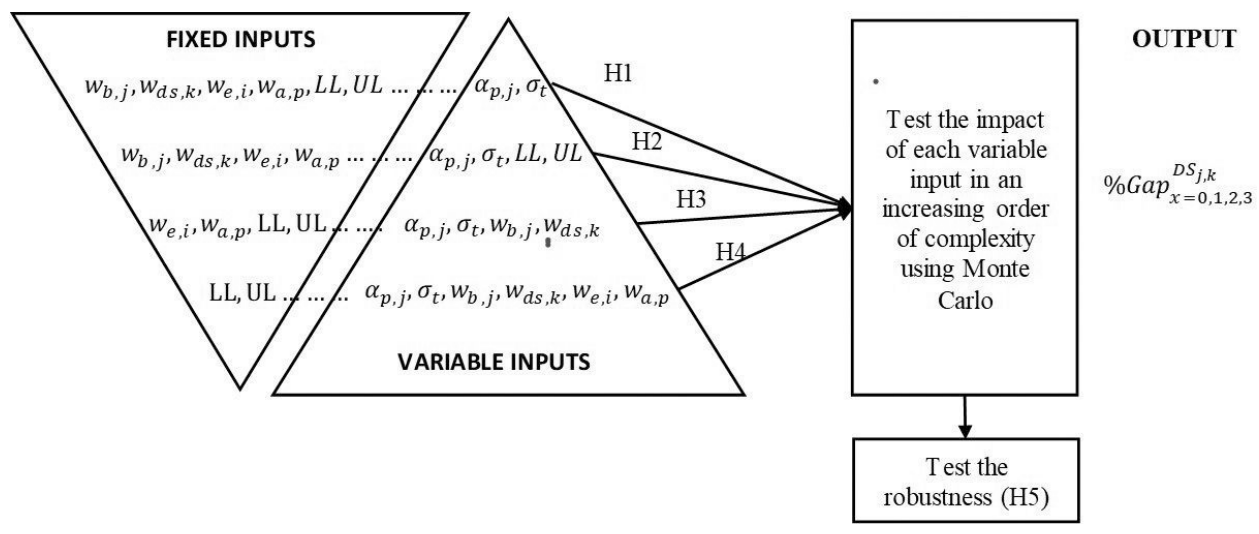

Fig. 4. Fixed and variable inputs for each hypothesis.

where $x=0,1,2,3$

$$
\operatorname{Gap}_{x}^{\mathrm{DS}_{j, k}}=\frac{\sum_{u=1}^{N}\left(\mathrm{Gap}^{\mathrm{DS}_{j, k}}=x\right)}{N} \times 100 \%, \quad \text { where } N=10,000 \text { or } 100,000 .
$$

To conduct the analysis, the proposed process methodology as illustrated in Fig. 4 was applied to examine and address the following hypothesis:

H1: Does a linear regression exists between $\% \mathrm{Gap}_{0} \mathrm{DS}_{j, k}$ and $\sigma_{t}$ ?

$\mathrm{H} 2$ : Do the Lower and Upper Limit values have an impact on the $\% \operatorname{Gap}_{x}{ }^{\mathrm{DS}_{j, k}}$ ?

H3: Do the strategic dimension weight values have an impact on $\% \mathrm{Gap}_{0}^{\mathrm{DS}_{j, k}}$ ?

$\mathrm{H} 4$ : Do the environment risk factor weight values influence the $\% \mathrm{Gap}_{0}{ }_{\mathrm{DS}_{j, k}}$ ?

H5: Robustness of the Monte Carlo analysis for $\% \operatorname{Gap}_{0} \mathrm{DS}_{j, k}$ ?

The proposed process method analyses the impact of the different criteria on the $\operatorname{Gap}_{0} \mathrm{DS}_{j, k}$ (i.e., the priority scores of both matrixes are assigned to the same zone).

\section{Results and Data Analysis}

All values $\beta_{i, k}$ are generated by Eq. (2), where $p$ and $\alpha_{p, j}$ are randomized. The standard deviation $\sigma_{t(\min )}$ and $\sigma_{t(\max )}$ must be identified to ensure that the analysis is performed over the entire range of $\sigma_{t} \in\left[\sigma_{t(\min )}, \sigma_{t(\max )}\right]$ so that the algorithm corresponds to reality. Experimentally, the lowest standard deviation $\sigma_{t(\min )} \approx 0$, is reached when $\alpha_{p, j}$ tends towards the upper limit +81 or lower limit -81 . The largest standard deviation $\sigma_{t(\max )}$ is reached for a mean $\mu=0$, and a arbitrary significance level $\alpha=0.0005$, which means a cumulative probability value of $\Phi_{\min }(x)=0.9995$. The value of the maximum standard deviation is derived from Eq. (7) by an iterative method to $\sigma_{t(\max )} \approx 23$, giving a process capability $C_{p} \min =1.17$. 


$$
\Phi(x)=\frac{1}{\sigma_{t} \sqrt{2 \pi}} \int_{-81}^{+81} e^{-\frac{x^{2}}{2 \sigma_{t}^{2}}} d x .
$$

For the purpose of this paper, each hypothesis is tested over $\sigma_{t}=[5,10,15,20,23,25,30]$.

\subsection{Response to $\mathrm{H1}$ : Does a linear regression exists between $\% \mathrm{Gap}_{0}^{\mathrm{DS}_{j, k}}$ and $\sigma_{t}$}

For this preliminary analysis, $N=10,000$, the Upper Limit (UL) is set at 45 and the Lower Limit (LL) at 9. The use of AHP requires compliance with certain rules for the weight of each criterion and the compounded weights of the risk factors, risk families, strategic perspectives and strategic dimensions. The values of $w_{b, j}, w_{d s, k}, w_{a, p}, w_{e, i} \in$ $[0,1]$ and $\sum_{j=1}^{4} w_{b, j}=1, \sum_{p=1}^{4} w_{a, p}=1, \quad \sum_{i=1}^{20} w_{e, i}=4$ and $\sum_{k=1}^{10} w_{d s, k}=4$. The weight values were selected in order to have an even spread of low, medium and high values.

A correlation analysis of the $\% \mathrm{Gap}_{0}{ }^{\mathrm{DS}_{j, k}}$ median versus the standard deviations $\left(\sigma_{t}\right)$ (Fig. 5) produced a Pearson correlation of -0.976 (with $p$-value $=0.000$ ) and a coefficient of determination $R^{2} \geq 0.99$, which demonstrates a very strong relationship according to Schober. ${ }^{57}$

However, this pre-analysis shows that the distribution of $\% \mathrm{Gap}_{0}^{\mathrm{DS}_{k}}$ responses for each strategic dimension (from 1 to 10 ) increases as $\sigma_{t}$ progresses from 1 to 30 . This statistical aberration has led us to study two other subjects: (1) the impact of the strategic dimension weight factors and (2) the Lower and Upper Limit values on the $\% \operatorname{Gap}_{x}^{\mathrm{DS}_{j, k}}$.

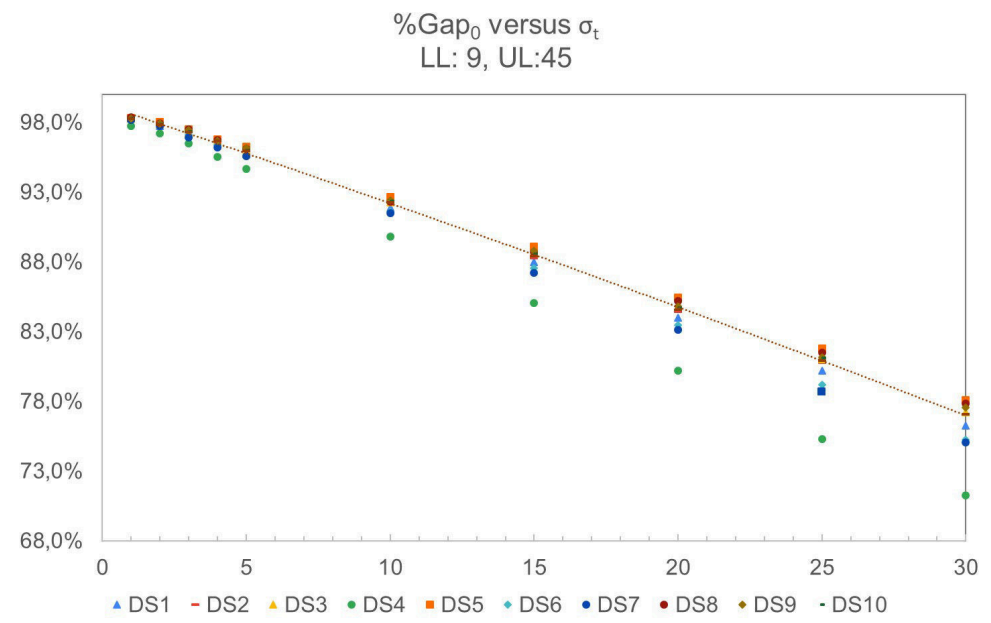

Fig. 5. Distribution graph of the priority score equal to 0. 


\subsection{Response to H2: Do the Lower and Upper Limit values have an impact on the $\% \operatorname{Gap}_{x \neq 0}^{\mathrm{DS}_{j, k}}$}

For this analysis, $N=100,000$, the values of $L L \in[1,20]$ and $U L \in[30,60]$. The values of $w_{b, j} ; w_{d s, k} ; w_{e, i} ; w_{a, p}$ are the same as above, and each data point is the median of $\% \operatorname{Gap}_{x \neq 0}^{D S_{j, k}}$, with $k \in[1,10]$. We notice that for each value of $\sigma_{t}$, the median of $\% \operatorname{Gap}_{2} \mathrm{DS}_{j, k}$ is equal to a constant $\left(C_{1, t}\right)$ whatever the values of LL, and similarly the median of $\% \operatorname{Gap}_{1}^{\mathrm{DS}_{j, k}}=C_{2, t}$ whichever the values of UL (Table 7).

For any LL values, the median of $\% \mathrm{Gap}_{1} \mathrm{DS}_{j, k}$ can be simplified by a 5 th degree polynomial regression with a $R^{2} \geq 0.99$ and a random residual plot (Fig. 6(a)). In addition, it is essential to identify the fluctuation of standard deviation for each data point in the LL value range as the impact of the strategic dimension weight factors on the results appear through the calculation of the standard deviation as shown in the following equation:

$$
\sigma_{\% \operatorname{Gap}_{x} \mathrm{DS}_{j, k}}=\sqrt{\frac{1}{9} \sum_{k=1}^{10}\left(\% \operatorname{Gap}_{x}^{\mathrm{DS}_{j, k}}-\% \operatorname{Gap}_{x}^{\left.\mathrm{DS}_{j, k}\right)} .\right.}
$$

In our case, the $\% \operatorname{Gap}_{2}{ }^{\mathrm{DS}_{j, k}}=C_{2, t}$ implies that $\sigma_{\% \mathrm{Gap}_{2}} \mathrm{DS}_{j, k}=$ constant, but the $\sigma_{\% \mathrm{Gap}_{x} \mathrm{DS}_{j, k}}$ for $x=1 ; 3$ shows a quite different picture (Fig. 6(a)). Also, to reveal the values of LL having the smallest impact on the sum of $\sigma_{\% \mathrm{Gap}_{1}} \mathrm{Ds}_{j, k}$ and $\sigma_{\% \mathrm{Gap}_{3}} \mathrm{Ds}_{j, k}$ over the complete range of $\sigma_{t}$, we identify the Min to be within the range $\in[12,16]$.

For any values of UL, the median of the $\% \mathrm{Gap}_{2} \mathrm{DS}_{j, k}$ is approached by a linear regression with a $R^{2} \geq 0.995$ and a Pearson correlation of -0.998 . The study of $\sigma_{\% \operatorname{Gap}_{x} \mathrm{DS}_{j, k}}$ for $x=1$ to 3 shows that $\sigma_{\% \mathrm{Gap}_{1}{ }_{j, k}}=$ ct as $\% \operatorname{Gap}_{1}^{\mathrm{DS}_{j, k}}=C_{1, t} ; \sigma_{\% \mathrm{Gap}_{2} \mathrm{DS}_{j, k}}$ can be modeled by a 2 nd degree polynomial regression with a $R^{2} \geq 0.99$ and a random residual plot; leaving the analysis of the Min of $\sigma_{\% \mathrm{Gap}_{3}} \mathrm{DS}_{j, k}$ across the range of UL to be reached for values $\geq 48$ (Fig. $6(\mathrm{~b})$ ).

\subsection{Response to H3: Do the strategic dimension weight values have an impact on $\% \mathrm{Gap}_{0}^{\mathrm{DS}_{j, k}}$}

The assumption in the model is that each cell value $\mu_{i}$ in the $4 \times 4$ matrix (within -81 and +81 ) is used to populate the associated cells in the $20 \times 10$ matrix using a normal distribution with a variable standard deviation $\sigma_{t}$ and a mean $\mu_{i}$. This axiom allows us to cover the complete spread of assessment, which can be made by the SME leaders. In this analysis, the strategic weight factor $\left(w_{\text {strategic }}\right)$ is calculated by multiplying $w_{b, j} \times w_{d s, k}=w_{\text {strategic }} \in[0,1]$. For each $\sigma_{t}$ and $w_{\text {strategic }}$, the Monte Carlo 

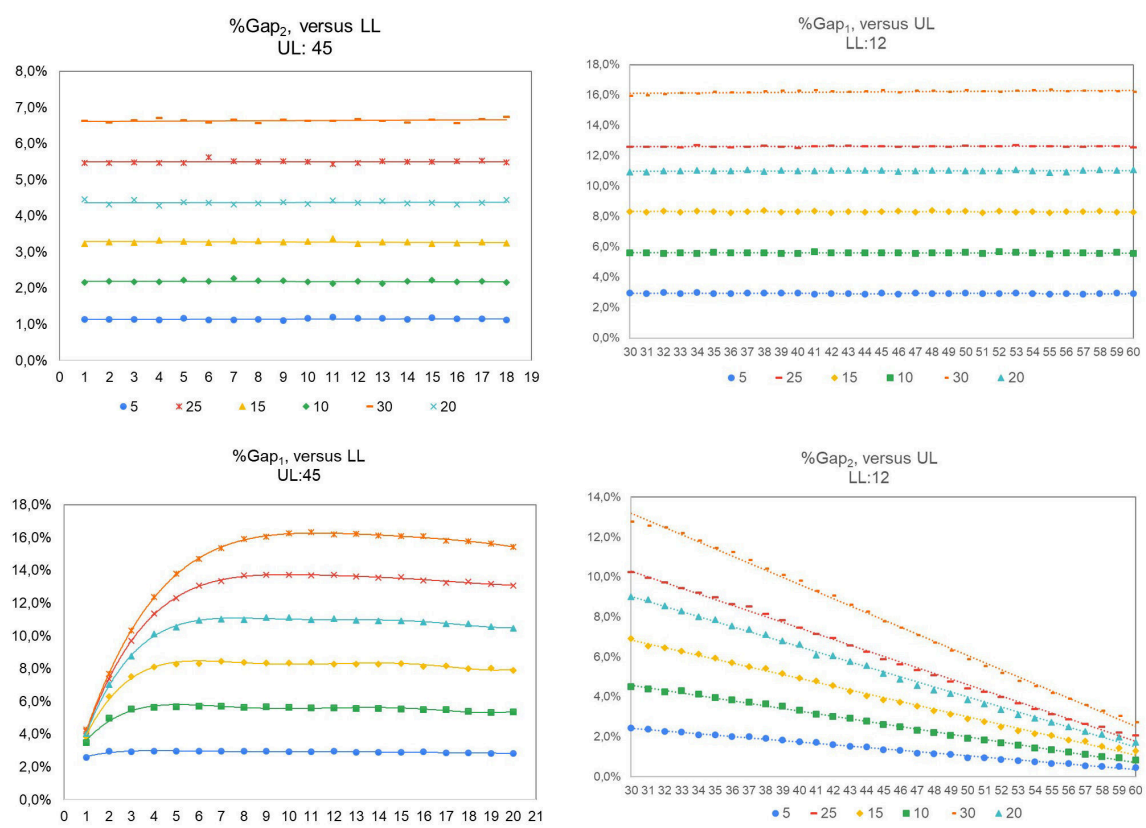

$\bullet 5 \times 25 \quad \bullet 15 \quad=10 \quad * 30 \quad \Delta 20$

Standard Deviation of $\% \mathrm{Gap}_{3}$, versus UL

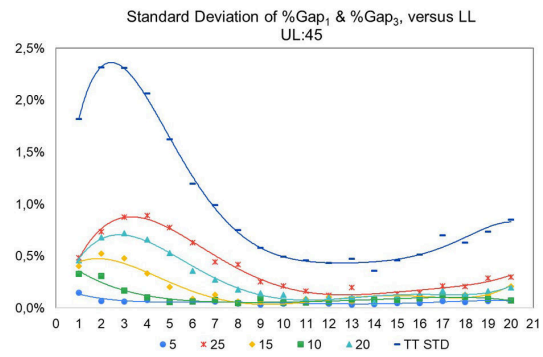

LL:12

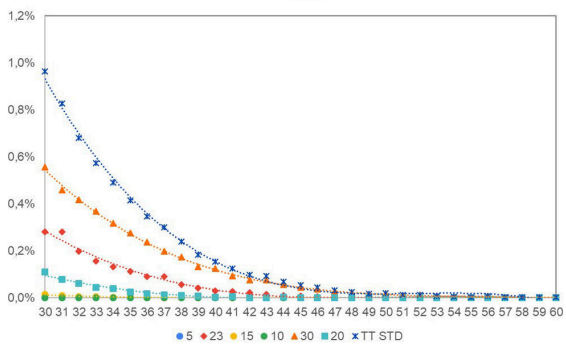

(a) Lower Limit

(b) Upper Limit

Fig. 6. Lower and upper limits impact on the priority score and standard deviation.

analysis is runned 10 times with a sample size of 10,000 to plot the curves $\% \operatorname{Gap}_{0} \mathrm{DS}_{j, k}$ over of the range of $w_{\text {strategic }}$ (Fig. 7). The values of $w_{e, i} ; w_{a, p}$ are identical as in paragraph 5.1.

The relationship between the two variables can be modeled by a 5 th degree polynomial regression with a $R^{2} \geq 0.98$ and a random residual plot. The weight of a strategic dimension has a strong impact on $\% \operatorname{Gap}_{0}^{\mathrm{DS}_{j, k}}$. Since all $\alpha_{p, j}$ and $\beta_{i, k}$ are randomly generated, as soon as $\left(1-w_{b, j} \times w_{d s, k}\right)$ exceeds a limit, the $\% \operatorname{Gap}_{0} \mathrm{DS}_{j, k}$ increases abnormally. The maximum $w_{\text {strategic }}$ for each $\sigma_{t}$ (Table 7 ) is reached when $\% \operatorname{Gap}_{0}^{\mathrm{DS}_{j, k}}=f\left(w_{\text {strategic }}, \sigma_{t}\right)$ ceases to satisfy a single variable linear regression, with a 


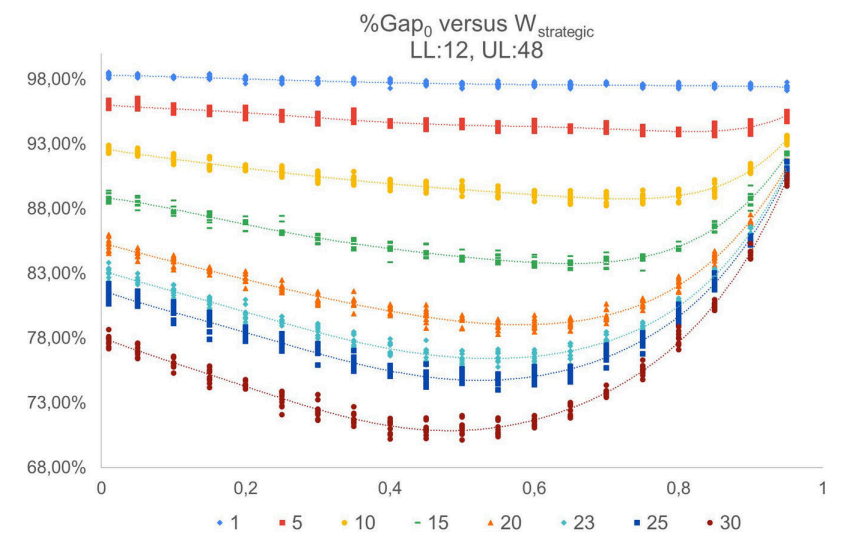

Fig. 7. Graph of the priority score equal to 0 versus strategic weight values.

coefficient of determination $R^{2} \geq 0.995$ as shown in the following equation:

$$
\% \operatorname{Gap}_{0}^{\mathrm{DS}_{j, k}}=\phi \times w_{\text {strategic }}+\varepsilon .
$$

\subsection{Response to H4: Do the environment risk factor weight values influence the $\% \mathrm{Gap}_{0}{ }^{\mathrm{DS}_{j, k}}$}

To finalize the study, the results of the above hypotheses were used to perform a Monte Carlo simulation with the values of $w_{e, i} ; w_{a, p} \in[0,1]$ and $\alpha_{p, j} \in[-81,+81]$ randomized and repeated over a sample size of 100,000 . The process was repeated for each $\sigma_{t}$ and over the range of $w_{\text {strategic }} \in[0,0.4]$ and then the $\% \mathrm{Gap}_{0}{ }^{\mathrm{DS}_{j, k}}$ results are plotted in Fig. 8.

Each curve can be approximated by a linear regression with a Pearson's correlation $<-0.99$ over the range of $\sigma_{t} \in[5,30]$. The final values of $(\phi)$ and $(\varepsilon)$ shown in Table 8 are slightly lower than those in Table 7 because the simulation incorporates the full range of risk factors and risk family weights.

In summary, the occurrence of the priority score assigned to the same zone $\operatorname{Gap}_{0}^{D S_{j, k}}$ in the least favourable scenario $\sigma_{t(\max )} \approx 23$ varies from $[82.38 \%, 76.44 \%]$.

\subsection{Response to H5: Robustness of the Monte Carlo analysis for $\% \operatorname{Gap}_{0} \mathrm{DS}_{j, k}$}

Robustness can be defined as the degree of insensitivity of a solution to the underlying assumptions within the model. To do so, the sampling efficiency of $\% \mathrm{Gap}_{0}^{\mathrm{DS}_{j, k}}$ is evaluated for 100, 500, 1000, 5000, 10000, 25000, 50000 and 100000 runs and at four specific nodes $\sigma_{t}=5,23$ and $w_{\text {strategic }}=0.05,0.4$. To account for stochastic 


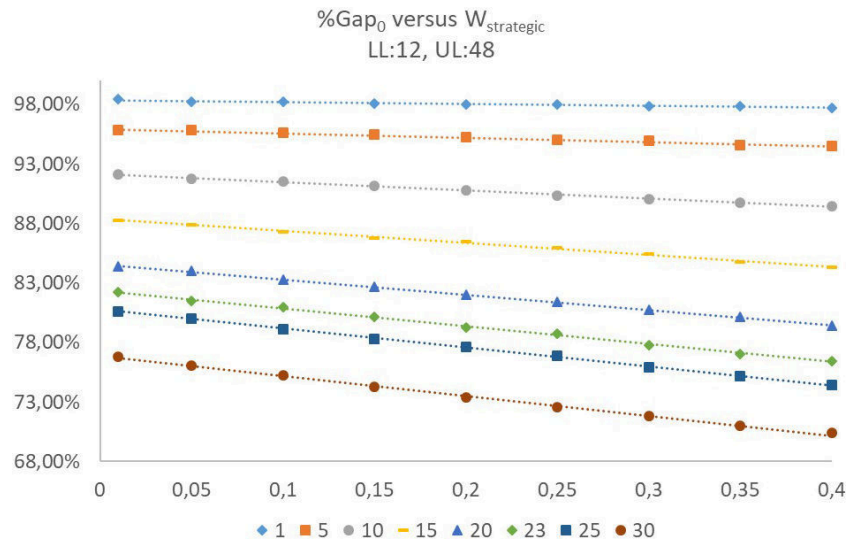

Fig. 8. Plot of the priority score equal to 0 over the entire range of $w_{e, i} ; w_{a, p}$.

Table 7. Lower and upper limits affect on nonidentical priority score.

\begin{tabular}{|c|c|c|c|c|c|c|}
\hline Gap & Limits & $\sigma_{t}$ & Constant & Value & $T$-value & $p$-value \\
\hline \multirow{6}{*}{ Median of $\% \mathrm{Gap}_{2}^{\mathrm{DS}_{j, k}}$} & \multirow[t]{6}{*}{$\mathrm{LL} \in[1,20]$} & 5 & $C_{1,5}$ & $1.13 \%$ & 99.35 & 0.000 \\
\hline & & 10 & $C_{1,10}$ & $2.20 \%$ & 140.00 & 0.000 \\
\hline & & 15 & $C_{1,15}$ & $3.31 \%$ & 186.13 & 0.000 \\
\hline & & 20 & $C_{1,20}$ & $4.37 \%$ & 198.83 & 0.000 \\
\hline & & 25 & $C_{1,25}$ & $5.49 \%$ & 302.77 & 0.000 \\
\hline & & 30 & $C_{1,30}$ & $6.66 \%$ & 282.72 & 0.000 \\
\hline \multirow{6}{*}{ Median of $\% \operatorname{Gap}_{1}^{\mathrm{DS}_{j, k}}$} & \multirow[t]{6}{*}{$\mathrm{UL} \in[30,60]$} & 5 & $C_{2,5}$ & $2.98 \%$ & 125.23 & 0.000 \\
\hline & & 10 & $C_{2,10}$ & $5.56 \%$ & 188.37 & 0.000 \\
\hline & & 15 & $C_{2,15}$ & $8.34 \%$ & 231.25 & 0.000 \\
\hline & & 20 & $C_{2,20}$ & $10.96 \%$ & 245.28 & 0.000 \\
\hline & & 25 & $C_{2,25}$ & $13.58 \%$ & 290.72 & 0.000 \\
\hline & & 30 & $C_{2,30}$ & $15.91 \%$ & 238.88 & 0.000 \\
\hline
\end{tabular}

Table 8. Maximum strategic weight $\left(w_{\text {strategic }}\right)$.

\begin{tabular}{lcccccc}
\hline Gap & $\sigma_{t}$ & Max $w_{\text {strategic }}$ & Linear slope $(\phi)$ & Constant $(\varepsilon)$ & Pearson correlation & Spearman Rho \\
\hline \%Gap $_{0} \mathrm{DS}_{j, k}$ & 5 & $\mathbf{0 . 4 9}$ & -0.0367 & $96.12 \%$ & -0.999 & -1.000 \\
& 10 & $\mathbf{0 . 4 3}$ & -0.0686 & $92.57 \%$ & -0.998 & -1.000 \\
& 15 & $\mathbf{0 . 4 2}$ & -0.1060 & $88.98 \%$ & -0.998 & -1.000 \\
& 20 & $\mathbf{0 . 4 7}$ & -0.1344 & $85.30 \%$ & -0.999 & -1.000 \\
& $\mathbf{0 . 4 6}$ & -0.1535 & $83.13 \%$ & -0.999 & -1.000 \\
& 25 & $\mathbf{0 . 4 7}$ & -0.1576 & $81.60 \%$ & -1.000 & -1.000 \\
& 30 & $\mathbf{0 . 4 0}$ & -0.1778 & $77.93 \%$ & -0.998 & -1.000 \\
\hline
\end{tabular}



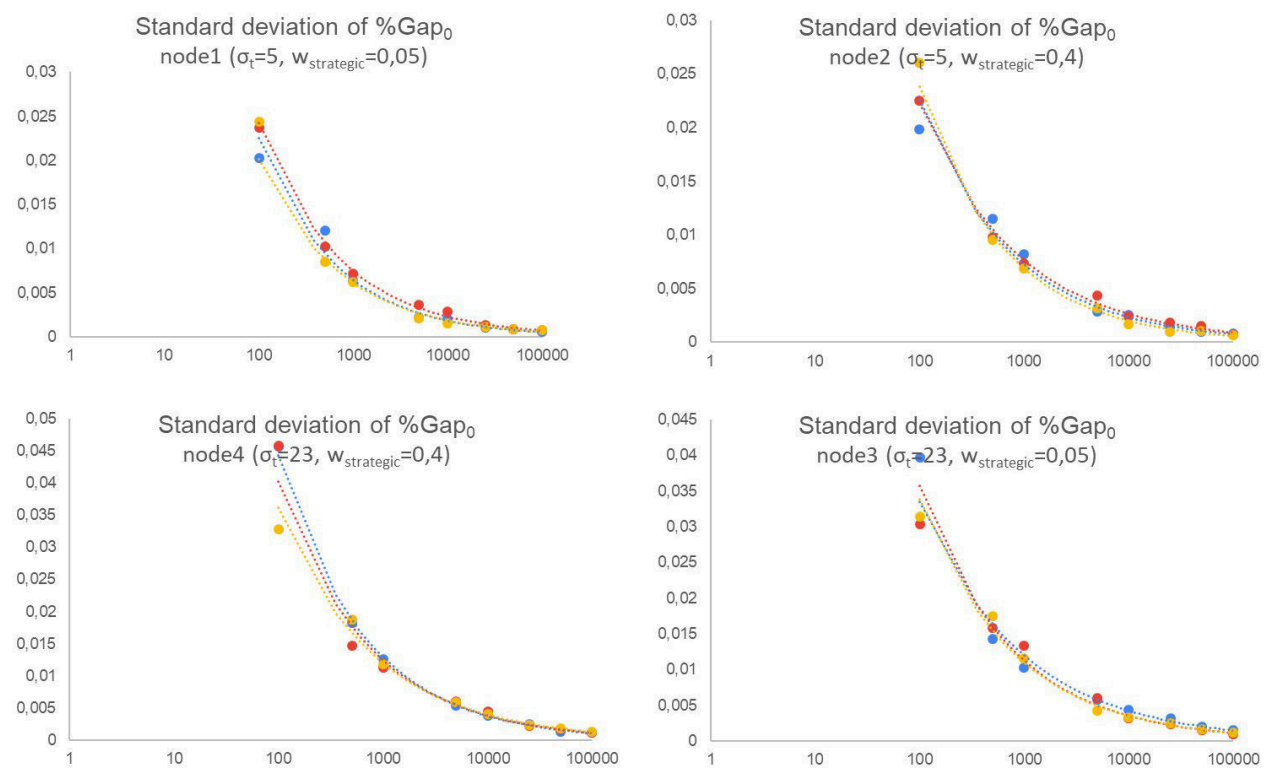

Fig. 9. Standard deviation plots of the priority score equal to 0 for three series of $20 n$-run sets.

Table 9. Linear characteristics of the priority score equal to 0.

\begin{tabular}{lccccc}
\hline Gap & $\sigma_{t}$ & Linear slope $(\phi)$ & Constant $(\varepsilon)$ & Pearson correlation & Spearman Rho \\
\hline \% Gap $_{0}{ }^{\mathrm{DS}_{j, k}}$ & 5 & -0.0362 & $95,54 \%$ & -0.990 & -0.983 \\
& 10 & -0.0693 & $92.16 \%$ & -0.999 & -1.000 \\
& 15 & -0.1007 & $88.37 \%$ & -0.998 & -1.000 \\
20 & -0.1277 & $84.58 \%$ & -1.000 & -1.000 \\
& 23 & $-\mathbf{0 . 1 5 0 0}$ & $\mathbf{8 2 . 3 8 \%}$ & $-\mathbf{0 . 9 9 9}$ & $-\mathbf{1 . 0 0 0}$ \\
& 25 & -0.1597 & $80.77 \%$ & -0.999 & -1.000 \\
& -0.1664 & $76.84 \%$ & -0.999 & -1.000 \\
\hline
\end{tabular}

variations in the generation of random numbers, three series of twenty repetitions of every $n$-run set are performed. The graphs in Fig. 9 confirm that the standard deviation of each series is decreasing with increasing numbers of runs. ${ }^{58}$

Since robustness refers to the probability of a certain level of performance, a oneway analysis of variance and standard deviation tests were carried out to compare means and standard deviation of the three series at the same four specific nodes and the 100000-run solution. The $p$-value for each test was greater than 0.05 at a significance level of 0.05 . These results indicate that the differences in means and standard deviations between the three series are not statistically significant, confirming that the Monte Carlo analysis is robust. 


\section{Discussion and Conclusion}

The objective of this study was to determine whether a simple Risk Management tool could be designed to identify and assess the impact of risks on the business strategic dimensions. A step-by-step analysis confirmed that the hypotheses were supported. Management decisions can be different from one person to another and from one business to another. The research has identified the effect of the weight of each criterion on the Priority Zone of each strategic dimension. In addition, the Monte Carlo simulation has revealed some important rules for the reduced matrix to be effective, namely $w_{b, j} \times w_{d s, k} \in[0,0.4], w_{e, i} ; w_{a, p} \in[0,0.9]$, Lower Limit $\in[12,16]$ and Upper Limit $\geq 48$.

\subsection{Managerial implications}

Studies show that most SME leaders fail to develop effective strategies due to three main factors: lack of time, methodology and inability to adapt to an ever-changing environment. Using the Balanced Scorecard framework, this paper sought to link the ten most recurring strategic dimensions to the four strategic perspectives: financial, customer, internal process, learning and innovation. The impact of the risk' factors are then introduced into the strategic risk matrix to identify the strategic dimensions on which the SME leader should focus his or her attention. The Monte Carlo simulation showed that a reduced strategic risk matrix (size $4 \times 4$ ) could provide the same quality of results as a full strategic risk matrix (size $20 \times 10)$ in $76.44 \%$ of cases, regardless of the weight of each input and the values of the risk factor. The reduced strategic risk matrix fully satisfies the Pareto concept that the majority of outcomes are often derived from a minority of inputs. ${ }^{59}$

This reduced risk matrix will enable the SME leader to create a positive organizational risk culture in which the concerns of all employees and the assessment of the environment risks can be captured. Through a shared and proactive identification of risks, the management can establish a positive climate to deal with today's potential crises, strengthen its ability to determine the best possible strategy and mitigate the possible disruptions. ${ }^{60}$

Moro and Fink ${ }^{61}$ indicated that banks play a critical role in financing businesses, particularly SMEs, as they have more difficulty accessing equity capital markets. The proposed SME strategic risk matrix could help lenders to finance SMEs by making faster and more objective decisions ${ }^{62,63}$ based on the actual business environment. As demonstrated by Ref. 5, strengthening the risk management capabilities of SME leaders has a direct impact on the long-term financial success and competitive advantage of the company. ${ }^{7}$ Finally, the reduced strategic risk matrix was named the VY matrix, from the Latin word "via" meaning a way or a path, in our case a road towards formalizing the SME strategy by assessing a limited numbers of risk factors. This Risk Management tool will enable SME leaders to formalize their strategy relatively quickly, in a structured manner and in accordance with its environment risks. 


\subsection{Future research}

Further investigation is needed to determine the weight of each variable (i.e., risk factor, risk family, strategic perspective and strategic dimension) through a survey of experts. It is sometimes impossible to provide an accurate judgment due to the complexity, vagueness and uncertainty of the problem. In order to capture the level of inconsistency and subjectivity in the Analytical Hierarchy Process, a review of the literature on multiplicative, additive or fuzzy approaches(64) (65) (66) will be conducted to identify the most appropriate tactic to improve the consistency of the pairwise comparison matrices.

This study is only the first brick in a larger research program aimed at adapting the BSC framework to the specific needs of SMEs so that the management team and the employees can easily formalize the business strategy. This application will be integrated into a web-based interface capable of supporting data entry, analysis and visualization by integrating the strategic risk assessment tool developed in this paper. The reasons for the late adoption of Business Intelligence (BI) in $\mathrm{SMEs}^{67}$ are similar to the reasons for the failure to formalize and implement a successful strategy, ${ }^{1}$ i.e., lack of time, human and financial resources, methodology and knowledge. We hypothesize that the development of a risk assessment and communication tool could help SMEs to hasten the adoption of BI tools.

\section{Acknowledgments}

We are grateful to Dr. Norlaily Yaacob, Faculty of Engineering and Computing, Coventry University, UK for her comments that greatly improved the quality of this paper and CESI, Campus Saint-Nazaire for funding this research.

\section{References}

1. G. Gueguen, Persistance des caractéristiques initiales du dirigeant et croissance de la PME, Bordeaux: 10ème Congrés International Francophone en Entrepreneuriat et PME (2010).

2. R. Grant, Contemporary Strategy Analysis, Text and Cases Editions (John Wiley \& Sons, New York, 2016).

3. E. M. Falkner and M. R. Hiebl, Risk management in SMEs: a systematic review of available evidence, The Journal of Risk Finance 16(12) (2015) 122-144.

4. L. Pereira, A. Tenera, J. Bispo and J. Wemans, A risk diagnosing methodlogy web-based platforms for micro, small and medium business: Remarks and enhancements, in Communications in Computer and Information Science (2015), pp. 340-356.

5. J. Belas, J. Dvorsky and J. Kubalek, Important factors of financial risk in the SME segment, Journal of International Studies 11(11) (2018) 80-92.

6. S. Marcelino-Sádaba, A. Pérez-Ezcurdia, A. M. Echeverría Lazcano and P. Villanueva, Project risk management methodology for small firms, International Journal of Project Management 32(12) (2014) 327-340. 
7. Y. B. Kraja and E. Osmani, Importance of external and internal environment in creation of competitive advantage to SMEs.(Case of SMEs, in the Northern Region of Albania), European Scientific Journal 11(113) (2015).

8. A. Rostani, J. L. Sommerville, L. Wong and C. Lee, Risk management implementation in small and medium enterprises in the UK construction industry, Engineering Construction and Architectural Management 22(11) (2015) 91-107.

9. M. Toulova, M. Tuzova and L. Vesela, Key risk factors in internationalisation of Czech engineering small and medium-sized firms, International Journal of Business and Globalisation 17(13) (2016) 404-422.

10. P. F. de Araujo Lima, M. Crema and C. Verbano, Risk management in SMEs: A systematic literature review and future directions, European Mangement Journal 38, (2020) 78-94.

11. C. Crovini, G. Ossola and B. Britzelmaier, How to reconsider risk management in SMEs? An advanced, Reasoned, European Management Journal, 2020.

12. B. Britzelmaier, M. Haberle and M. Landwehr, Risk management in German small and medium-sized enterprise, International Journal of Entrepreneurship and Small Business 24(14) (2015) 548-571.

13. S. Chatterjee, R. M. Wiseman, A. Fiegenbaum and C. E. Devers, Integrating behavioural and economic concepts of risk into strategic management: The Twain shall meet, Long Range Planning 36 (2003) 61-79.

14. A. D. Coulibaly, La défaillance des PME Belges: Analyse des Déterminants et Modélisation Statistique (Université Catholique de louvain, Louvain-la-Neuve) (2004).

15. P. L. Walker and W. G. Schenkir, Montvale, NJ: Institute of Management Accountants, 2018.

16. H. T. Gerard, The Relevance of Porter's Five Forces in Today's Innovative and Changing Business Environment (2018).

17. C. Verbano and K. Venturini, Managing risks in SMEs: A literature review and research agenda, Journal of Technology Management \& Innovation 8(13) (2013) 186-197.

18. A. Islam and D. Tedford, Risk determinants of small and medium-sized manufacturing enterprises (SMEs) - an exploratory study in New Zealand, Journal of Industrial Engineering International 8(11) (2012) 1-12.

19. K. Grant, D. Edgar, A. Sukumar and M. Meyer, 'Risky business': Perceptions of ebusiness risk by UK small and medium sized enterprises (SMEs), International Journal of Information Management 34 (2014) 99-122.

20. J. Olah, Z. Virglerova, J. Popp, J. Kliestikova and S. Kovacs, The assessment of nonfinancial risk sources of SMES in the V4 countries and Serbia, Sustainability 11(17) (2019) 4806.

21. C. Chittithaworn, M. A. Islam, T. Keawchana and D. H. Yusuf, Factors affecting business success of small \& medium enterprises (SMEs) in Thailand, Asian Social Science $\mathbf{7}(15)$ (2011) 180-190.

22. S. M. Houghton, M. Simon, K. Aquino and C. B. Goldberg, No safety in numbers, Group E Organization Management 25(14) (2000) 325-353.

23. A. Sukumar, D. Edgar and K. Grant, An investigation of e-business risks in UK SMEs, World Review of Entrepreneurship, Management and Sustainable Development 7(14) (2011) 380-401.

24. W. Rudnicki and I. Vagner, Methods of strategic analysis and proposal method of measuring productivity of a company, Zeszyty Naukowe Malopolskiej Wyższej Szkoly Ekonomicznej w Tarnowie 2(125) (2014) 175-184. 
25. M. Tavana, M. Zareinejad, D. Di Caprio and M. A. Kaviani, An integrated intuitionistic fuzzy AHP and SWOT method for outsourcing reverse logistics, Applied Soft Computing (2016) 544-557.

26. X. Gimbert, J. Bisbe and X. Mendoza, The role of performance measurement systems in strategy formulation processes, Long Range Planning 43(14) (2010) 477-497.

27. J. W. Smither and M. London, Performance Management: Putting Research into Action (Wiley Imprint, San Francisco, 2009).

28. R. S. Kaplan and D. P. Norton, Strategic learning \& the balanced scorecard, Strategy $\&$ Leadership 24(15) (1996) 18-24.

29. K. J. Fernandes, V. Raja and A. Whalley, Lessons from implementing the balanced scorecard in a small and medium size manufacturing organization, Technovation 26(1516) (2006) 623-664.

30. P. Taticchi, F. Tonelli and L. Cagnazzo, Performance measurement and management: A literature review and a research agenda, Measuring Business Excellence 14(11) (2010) $4-18$.

31. P. Kueng, Process performance measurement system: a tool to support process-based organizations, Total Quality Management 11 (2000) 67-85.

32. M. Hudson, A. Smart and M. Bourne, Theory and practice in SME performance measurement systems, International Journal of Operations 89 Production Management 21 (18) (2001) 1096-1115.

33. C. D. Ittner, D. F. Larcker and T. Randall, Performance implications of strategic performance measurement in financial services firms, Accounting, Organizations and Society 28 (2003) 715-741.

34. OCDE, Oslo manual: Guidelines for collecting and interpreting innovation data, Éd., Statistical Office of the European communities, no. 4, 2005.

35. T. Watts and C. J. McNair-Connolly, New performance measurement and management control systems, Journal of Applied Accounting Research 13 (2012) 226-241.

36. A. P. A. Payara, A Dashboard for Lean Companies: A proposed model with the collaboration of ten large italian enterprises, chez15th Eurasia Business and Economics Society Conf., 2016.

37. K. Baird, The effectiveness of strategic performance measurement systems, International Journal of Productivity and Performance Management 66(11) (2017) 3-21.

38. L. Lucianetti, C. J. Jabbour, A. Gunasekaran and H. Latan, Contingency factors and complementary effects of adopting advanced manufacturing tools and managerial practices: Effects on organizational measurement systems and firms' performannce, International Journal of Production Economics 200 (2018) 318-328.

39. U. Bolukbas and A. F. Guneri, Knowledge-based decision making for the technology competency, Applied Soft Computing 67 (2018) 781-799.

40. E. Cagno, A. Neri, M. Howard, G. Brenna and A. Trianni, Industrial sustainability performance measurement systems: A novel, Journal of Cleaner Production 230 (2019) $1354-1375$.

41. T. A. Carbone and D. D. Tippett, Project risk management using the project risk FMEA, Engineering Management Journal 16(14) (2004) 28-35.

42. S. S. Gao, M. C. Sung and J. Zhang, Risk management capability building in SMEs: A social capital perspective, International Small Business Journal 31(16) (2012) 677-700.

43. L. Radder and L. Louw, The SPACE Matrix: A tool for calibrating competition, Long Range Planning 31(14) (1998) 549-559.

44. T. L. Saaty, Decision making with the analytic hierarchy process, International Journal of Services Sciences 1(11) (2008) 83. 
45. L. Jing, B. Chen, B. Zhang, P. Li and J. Zheng, Monte Carlo simulation-aided analytic hierarchy process approach: Case study of assessing preferred non-point-source pollution control best management practices, Journal of Environmental Engineering 139(15) (2013) 618-626.

46. N. Yaraghi, P. Tabesh, P. Guan and J. Zhuang, Comparison of AHP and Monte Carlo AHP under different levels of uncertainty, IEEE Transactions on Engineering Management 62(11) (2014) 122-132.

47. S. Luthra, S. Mangla, V. Venkatesh and S. Jakhar, Management of risks in sustainable supply chain using AHP and Monte Carlo simulation, Managerial Strategies for Business Sustainability During Turbulent Times (2018) 58-76.

48. A. Darko, A. P. Chan, E. E. Ameyaw, E. K. Owusu, E. Pam and D. Edwards, Review of application of analytic hierarchy process (AHP) in construction, International Journal of Construction Management 19(15) (2019) 436-452.

49. G. Mavrotas, O. Pechak, E. Siskos, H. Doukas and J. Psarras, Robustness analysis in Multi-objective mathematical programming using Monte Carlo simulation, European Journal Operational Research (2015) 193-201.

50. F. Le Roy, Les Stratégies de l'entreprise, 3rd édn. (Dunod, 2012).

51. T. Aven and O. Renn, Risk Management and Governance: Concepts, Guidelines and Applications (Springer Science \& Business Media, New York, 2010).

52. J. M. Vasnier, N. Maranzana, N. Messaadia and A. Aoussat, Preliminary design and evaluation of strategic dashboards through the technology acceptance model, in Proc. Design Society: DESIGN Conf., 2020.

53. L. J. Cox, What's wrong with risk matrices? Risk Analysis 28(12) (2008) 497-512.

54. E. Cardinaels and P. Van Veen-Dirks, Financial versus non-financial information: The impact of information organization and presentation in a Balanced Scorecard, Accounting, Organizations and Society 35(16) (2010) 565-578.

55. T. Gurbuz, A modified strategic position and action evaluation (SPACE) matrix method, in Proc. Int. MultiConf. Engineers and Computer Scientists, Vol. 2, 2013.

56. N. J. Duijm, Recommendations on the use and design of risk matrices, Safety Science $\mathbf{7 6}$ (2015) 21-31.

57. P. Schober, C. Boer and L. A. Schwarte, Correlation coefficients: Appropriate use and interpretation, Anesthesia \& Analgesia 126(15) (2018) 1763-1768.

58. H. Janssen, Monte-Carlo based uncertainty analysis: Sampling efficiency and sampling convergence, Reliability Engineering \& System Safety 1109 (2013) 123-132.

59. T. Powell and T. Sammut-Bonnici, Pareto Analysis, Wiley Encyclopedia of Management (Wiley, New York, 2015).

60. A. Dumitrescu, A. A. Purcărea, O. D. Negoiţă and O. Negoiţă, Research regarding connections between risks and processes within small and medium enterprises, Procedia Technology 19 (2015) 1038-1044.

61. A. Moro and M. Fink, Managers' trust and credit access for SMEs, Journal of Banking $\mathscr{E}$ Finance 37(3) (2013) 927-936.

62. J. A. Watkins, A literature review of small and medium enterprises (SME) risk management practices in South Africa, African Journal of Business Management 6(121) (2012) 6324-6330.

63. G. Kou, Y. Xu, Y. Peng, F. Shen, Y. Chen, K. Chang and S. Kou, Bankruptcy prediction for SMES using transactional data and two-stage multiobjective feature selection, Decision Support Systems 140 (2021) 113429.

64. U. Bolukbas and A. F. Guneri, A fuzzy multi-criteria decision approach for measuring technology competency performance of SMEs, Sigma Journal of Engineering 83 Natural Sciences 8(11) (2017) 31-40. 
65. G. Kou, D. Ergu, C. Lin and Y. Chen, Pairwise comparison matrix in multiple criteria decision making, Technological and Economic Development of Eeconomy 22(5) (2016) $738-765$.

66. G. Kou, D. Ergu, and J. Shang, Enhancing data consistency in decision matrix: Adapting Hadamard model to mitigate judgment contradiction, European Journal of Operational Research 236(1) (2014) 261-271.

67. K. Gudfinnsson and M. Strand, Challenges with BI adoption in SMEs, chez, 8th Int. Conf. Information, Intelligence, Systems $\&$ Applications (IISA), 2017. 